(C). М. Кліщ, О. М. Якимчук

Тернопільсъкий нащіональний медичний університет ілені І. Я. Горбачевсъкозо МОЗ України

\title{
ВПЛИВ ТИРЕОЇДНИХ ГОРМОНІВ ТА ЗАСОБІВ ДЛЯ НАРКОЗУ НА ОБМІН ФОЛАТІВ В ОРГАНІЗМІ ЩУРІВ В ЕКСПЕРИМЕНТІ
}

Мета дослідження - з'ясувати особливості реакції фролатного обміну піддослідних тварин за умов змодельованого гіпертиреозу на дію різних засобів для наркозу.

Матеріали та методи. Для моделювання стану гіпертиреозу щурам вводили L-тироксин протягом 21 дня. Порівнювали вплив еутиреозу та гіпертиреозу на рівні гомоцистеїну та фолієвої кислоти на введення тіопенталу натрію та дексмедетомідину в експерименті.

Результати дослідження та їх обговорення. В плазмі крові тварин з експериментальним гіпертиреозом спостерігали зміни рівня гомоцистеїну та фолієвої кислоти під впливом тіопенталу натрію та дексмедетомідину гідрохлориду за умов гіпер- та еутиреозу.

Висновки. Активація обмінних процесів щитоподібної залоз впливає на універсальні системи захисту організму, що проявляється особливо яскраво в умовах операційного та періопераційного стресу порушенням фролатного обміну, що обумовлює підвищений ризик тромбоутворення та пошук засобів медикаментозної корекції порушеного гомеостазу.

Ключові слова: гомоцистеїн; фолієва кислота; гіпертиреоз; тіопентал натрію; дексмедетомідин.

ВЛИЯНИЕ ТИРЕОИДНЫХ ГОРМОНОВ И СРЕДСТВ ДЛЯ НАРКОЗА НА ОБМЕН ФОЛАТОВ В ОРГАНИЗМЕ КРЫС В ЭКСПЕРИМЕНТЕ

Цель исследования - выяснить особенности реакции фролатного обмена подопытных животных в условиях смоделированного гипертиреоза на действие различных средств для наркоза.

Материалы и методы. Для моделирования состояния гипертиреоза крысам вводили L-тироксин в течение 21 дня. Сравнивали влияние эутиреоза и гипертиреоза на уровни гомоцистеина и фролиевой кислоты на введение тиопентала натрия и дексмедетомидина в эксперименте.

Результаты исследования и их обсуждение. В плазме крови животных с экспериментальным гипертиреозом наблюдали изменения уровня гомоцистеина и фолиевой кислоты под влиянием тиопентала натрия и дексмедетомидинагидрохлорида в условиях гипер- и эутиреоза.

Выводы. Активация обменных процессов щитовидной железы влияет на универсальные системы защиты организма проявляется особенно ярко в условиях операционного и периоперационного стресса нарушением фолатного обмена, обусловливает повышенный риск тромбообразования и поиск средств медикаментозной коррекции нарушенного гомеостаза.

Ключевые слова: гомоцистеин; фолиевая кислота; гипертиреоз; тиопентал натрия; дексмедетомидин.

INFLUENCE OF THYROID HORMONES AND DRUGS FOR ANESTHESIA ON FOLLATE METABOLISM IN RATS IN THE EXPERIMENT

The aim of the study - to determine the characteristics of the reaction of folate metabolism in experimental animals under conditions of simulated hyperthyroidism to the action of various drugs for anesthesia.

Material and Methods. To simulate the state of hyperthyroidism, rats were administered L-thyroxine for 21 days. The effect of euthyroidism and hyperthyroidism on the level of homocysteine and folic acid on the introduction of sodium thiopental and dexmedetomidine in the experiment was compared.

Results and Discussion. In the blood plasma of animals with experimental hyperthyroidism, changes in the level of homocysteine and folic acid were observed under the influence of sodium thiopental and dexmedetomidine hydrochloride under conditions of hyper- and euthyroidism.

Conclusions. Activation of metabolic processes of the thyroid gland affects the universal defense systems of the body, which is especially evident in conditions of operative and perioperative stress, folate metabolism, which causes an increased risk of thrombosis and the search for drugs to correct disturbed homeostasis.

Key words: homocysteine; foliac acid; hyperthyroidism; sodium thiopental; dexmedetomidine.

ВСтУп. Збільшення поширеності гіпертиреозу обґрунтовує доцільність проведення експериментальних досліджень для вивчення механізмів впливу тиреоїдних гормонів на ряд метаболічних процесів та гомеостаз організму при еутиреозі та гіпертиреозі в експерименті $[1,2]$. Високі ризики інтра- і післяопераційних ускладнень пов'язані з безпосереднім токсичним впливом надлишку гормонів щ3 на серцево-судинну, нервову, ендокринну та інші системи організму [1-3]. Високий ступінь варіабельності цих впливів на організм обґрунтовує актуальність проблеми оптимізації анестезіологічної допомоги при ургентних операціях з приводу різних нозологій на фроні патології щ3, що посилюється на фроні передопераційного стресу [4].

Більшість патологічних процесів в організмі є універсальними. Підвищення в крові концентрації сірковмісної 
амінокислоти гомоцистеїну (ГЦ) є серйозним фактором розвитку захворювань серцево-судинної системи, атеросклерозу, гіпертензії, венозного тромбозу [2]. Регуляція метаболізму сірковмісних амінокислот здійснюється на різних рівнях, у тому числі й тиреоїдними гормонами. Встановлено, що гіпертиреоз $є$ незалежним фактором, який призводить до збільшення концентрації ГЦ у крові та ризику розвитку серцево-судинних захворювань. Проте конкретні молекулярні механізми впливу тиреоїдних гормонів на обмін сірковмісних амінокислот залишаються невідомими. Одним із таких механізмів $є$ їх вплив на про- та антиоксидантну системи захисту [2]. Особливість впливу гіперфункції щитоподібної залози на процеси вільнорадикального окиснення, утворення активних фрорм кисню, на процеси, які виконують численні регуляторні функкції, потребує вивчення $[2,5,6]$.

МЕТА ДОСЛІДЖЕННЯ - З'ясувати особливості реакції складових фролатного обміну піддослідних тварин на дію різних засобів для наркозу за умов модельованого гіпертиреозу.

МАТЕРІАЛИ ТА МЕТОДИ. Дослідження виконане на 60 статевозрілих безпородних білих щурах-самцях масою

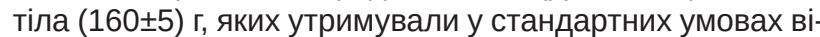
варію. Всі маніпуляції з експериментальними тваринами проводили із дотриманням правил Європейської конвенції про захист хребетних тварин, що використовуються для дослідних та інших наукових цілей», а також згідно 3 Науково-практичними рекомендаціями з утримання лабораторних тварин та роботи з ними [7].

Піддослідні тварини були поділені на групи: I група - інтактна (10 щурів); на тваринах II групи був модельований експериментальний гіпертиреоз (10 щурів); III групі тварин вводили тіопентал натрію на фроні еутиреозу (10 щурів); IV група тварин отримувала тіопентал-натрію на фоні експериментального гіпертиреозу (10 щурів); V групі тварин вводили дексмедетомідин на фроні еутиреозу (10 щурів), VI групі вводили дексмедетомідин на фроні експериментального гіпертиреозу (10 щурів) (табл. 1).

Гіпертиреоз моделювали шляхом інтрагастрального введення L-тироксину на $1 \%$ розчині крохмалю по 200 мкг/добу на 1 кг маси тіла щоденно протягом 21 дня [2]. Тіопентал натрію вводили внутрішньоочеревинно 3 розрахунку 20 мг/кг маси тіла щурів $[8,9]$. Дексмедетомідину гідрохлорид вводили внутрішньоочеревинно з розрахунку 1 мкг/кг маси тіла експериментальних тварин [10].

Рівень оксидативного стресу у щурів вивчали за вмістом у плазмі крові дієнових конюгат (ДК) за методом, описаним В. Б. Гавриловим [11] і ТБК-активних продуктів, як описано у роботі И. Д. Стальная $[12,13]$. Рівень гомоцистеїну визначали в сироватці крові імуноферментним методом із застосуванням набору фрірми «Axis-Shield» (Велика Британія). ТТГ визначали імуноферментним ме- тодом з використанням наборів фрірми «Диагностические системы» (Російська Федерація) [13, 14].

Отриманий в результаті експерименту циоровий матеріал був систематизований та оброблений за допомогою методів варіаційної статистики 3 використанням програми Microsoft Exel 9,0.

РЕЗУЛЬТАТИ ДОСЛІДЖЕННЯ ТА ЇХ ОБГОВОРЕНня. Токсичність різних засобів для наркозу за умов експериментального гіпертиреозу оцінювали за рівнями гомоцистеїну та фолієвої кислоти.

Аналіз отриманих результатів показав, що експериментальний гіпертиреоз достовірно змінює рівні фролієвої кислоти та гомоцистеїну в сироватці крові тварин. Показники фролієвої кислоти знижувались в 1,6 раза, порівняно з групою контрольних тварин. Так, рівень фролієвої кислоти при еутирозі досягав значення $(16,74 \pm 0,13)$ ум. од та $(10,64 \pm 0,15)$ ум. од. при гіпертиреозі у експериментальних тварин, $(p<0,05)$, що достовірно перевищувало показники групи контролю. Значення гомоцистеїну дорівнювали $(8,40 \pm 0,14)$ мкмоль/л при еутирозі та $(9,35 \pm 0,16)$ мкмоль/л - при експериментальному гіпертиреозі $(p<0,05)$.

За умови введення тіопенталу натрію (III група) та дексмедетомідину (V група) відбувається збільшення рівня гомоцистеїну в сироватці крові тварин на фоні еутиреозу. Встановлено помірне зростання рівня гомоцистеїну $((10,31 \pm 0,16)$ мкмоль/л) у 1,3 раза $(p<0,05)$ в III групі на тлі введення тіопенталу натрію та в 1,1 раза $((8,96 \pm 0,18)$ мкмоль/л) в V групі тварин, в яких використовували дексмедетомідин, порівняно з показниками у групі інтактних тварин відповідно $(p<0,05)$. Гіпертиреоз призводить до порушення процесів фолатного обміну. Зафріксоване суттєве зростання рівня гомоцистеїну в групах зі змодельованим гіпертиреозом при введенні тіопенталу натрію (IV група) у 1,72 раза $((13,95 \pm 0,17)$ мкмоль/л $(p<0,05))$ та лише у 1,15 раза $((9,29 \pm 0,11)$ мкмоль/л, $(p>0,05))$ в групі з дексмедетомідином (VI група).

Порівняно з еутиреозом, гіпертиреоз викликав тенденцію до падіння рівня фолієвої кислоти (ФК). Концентрація ФК у сироватці крові досліджуваних тварин становила в І групі тварин $(16,74 \pm 0,13)$ ум. од. та $(10,64 \pm 0,15)$ ум. од. у II групі тварин $(p<0,05)$. Застосування тіопенталу за умови еутиреозу (III група) приводило до зниження рівня фолієвої кислоти в 1,14 раза відповідно $(14,67 \pm 0,26)$ ум. од. $(p<0,05))$. У IV групі тварин при експериментальному гіпертиреозі та застосуванні тіопенталу натрію ці показники досягають значення $(9,07 \pm 0,16)$ ум. од., що в 1,84 раза вище показників інтактних тварин $(p<0,05)$. За умови застосування дексмедетомідину при еутиреозі (V група) рівень фролієвої кислоти становив $(16,20 \pm 0,21)$ ум. од. та $(15,79 \pm 0,17)$ ум. од. (р>0,05), відповідно, при гіпертиреозі (VI група), що свідчить про щадну дію дексмедетомідину на обмін фролатів при еутиреозі та гіпертиреозі (табл. 2).

Таблиця 1. Поділ тварин на групи

\begin{tabular}{|l|c|c||}
\hline \multicolumn{1}{|c|}{ Група тварин } & Кількість тварин & Вид знеболювання \\
\hline I група & 10 & Еутиреоз \\
\hline II група & 10 & Гіпертиреоз \\
\hline III група & 10 & Тіопентал натрію+ еутирео3 \\
\hline IV група & 10 & Тіопентал натрію +гіпертирео3 \\
\hline V група & 10 & Дексмедетомідин+ еутирео3 \\
\hline VI група & 10 & Дексмедетомідин+ гіпертирео3 \\
\hline
\end{tabular}


Акушерство та гінекологія

Таблиця 2. Рівні гомоцистеїну, фолієвої кислоти, малонового діальдегіду та дієнових кон'югатів у тварин 3 експериментальним гіпертиреозом за умови застосування різних препаратів для наркозу (M $\pm m), n=10$

\begin{tabular}{|l|c|c|c|c|c|c|}
\hline \multicolumn{1}{|c|}{ Показники } & I група & II група & III група & IV група & V група & VI група \\
\hline Гомоцистеїн, мкмоль/л & $8,40 \pm 0,14$ & $9,35 \pm 0,16^{*}$ & $10,31 \pm 0,16^{*}$ & $13,95 \pm 0,17^{*}$ & $8,96 \pm 0,18$ & $9,29 \pm 0,11^{*}$ \\
\hline Фолієва кислота, ум. од. & $16,74 \pm 0,13$ & $10,64 \pm 0,15^{*}$ & $14,67 \pm 0,26^{*}$ & $9,07 \pm 0,16^{*}$ & $16,20 \pm 0,21$ & $15,79 \pm 0,17^{*}$ \\
\hline МДА, мкмоль/л & $3,67 \pm 0,6$ & $7,05 \pm 0,14^{*}$ & $4,83 \pm 0,13^{*}$ & $7,84 \pm 0,1^{*}$ & $4,31 \pm 0,07^{*}$ & $6,79 \pm 0,16^{*}$ \\
\hline ДК, ум. од./мл & $1,18 \pm 0,07$ & $2,21 \pm 0,05^{\star}$ & $1,34 \pm 0,08^{\star}$ & $2,56 \pm 0,13^{\star}$ & $1,29 \pm 0,09^{*}$ & $2,32 \pm 0,09$ \\
\hline
\end{tabular}

Примітка. *- величини, які статистично достовірно відрізняються від аналогічних показників у контрольній групі тварин $(p<0,05)$.

Дисбаланс в системі фролатного обміну виникає за рахунок різкої активації пулу вільних радикалів, ініційованих експериментальним гіпертиреозом.

Результати дослідження мембранотоксичної дії різних засобів для наркозу при експериментальному гіпертиреозі оцінювали за активністю срерментної антиоксидантної системи захисту та показників ліпопероксидації.

Аналіз отриманих результатів показав, що експериментальний гіпертиреоз значно активує процеси редокс-системи. Порівняно з еутиреозом, гіпертиреоз спричиняв зростання початкових продуктів пероксидного окиснення ліпідів. Концентрація ДК у сироватці крові дослідних тварин зростала і становила у першій групі тварин $(1,18 \pm 0,07)$ ум. од., в другій - $(2,21 \pm 0,05)$ ум. од. $(p<0,05)$. Застосування тіопенталу за умови еутиреозу (третя група) призводило до зростання ДК в 1,1 раза, відповідно $(1,34 \pm 0,08)$ ум. од. $(p<0,05))$. В четвертій групі тварин при експериментальному гіпертиреозі та застосуванні тіопенталу натрію ці показники досягали значення $(2,56 \pm 0,13)$ ум. од., що в 1,6 раза перевищує показники інтактних тварин $(\mathrm{p}<0,05)$. За умови застосування дексмедетомідину при еутиреозі (V група) рівень ДК становив $(1,29 \pm 0,09)$ ум. од. та $(2,32 \pm 0,09)$ ум. од. $(p<0,05)$ відповідно при гіпертиреозі (VI група) (див. табл. 2).

Показники ТБК-активних продуктів зростали в 1,8-1,9 раза у порівнянні з групою інтактних тварин. Так, початкові продукти пероксидного окиснення ліпідів (дієнові кон'югати) досягали рівня $(1,18 \pm 0,07)$ ум. од. при еутиреозі та $(2,21 \pm 0,05)$ ум. од. - при гіпертиреозі в експериментальних тварин ( $<<0,05)$, порівняно з групою інтактних тварин. Концентрація проміжного показника пероксидного окиснення ліпідів - малонового діальдегіду (МДА) при еутиреозі склала $(3,67 \pm 0,6)$ мкмоль/л, а при експериментальному гіпертиреозі зростала до $(7,05 \pm 0,14)$ мкмоль/л $(p<0,05)$.

\section{СПИСОК ЛІТЕРАТУРИ}

1. 2015 American thyroid association management guidelines for adult patients with thyroid nodules and differentiated thyroid cancer: the american thyroid association guidelines task force on thyroid nodules and differentiated thyroid cancer / B. R. Haugen, E. K. Alexander, K. C. Bible [et al.] // Thyroid. - 2016. - Vol. 26 (1). - P. 1-133.

2. Нечипорук В. М. Вплив тиреоїдних гормонів на процеси реметилування та транссульфування сірковмісних амінокислот в органах щурів / В. М. Нечипорук, Н. В. Заічко, М. М. Корда // Медична та клінічна хімія. - 2017. - № 19 (1). - C. 12-16.

3. Homocysteine, folate, and cobalamin levels in hyperthyroid women before and after treatment / A. Orzechowska-
При введенні тіопенталу натрію (III група) та дексмедетомідину (V група) у еутиреоїдних тварин концентрація ТБК-активних продуктів у сироватці крові тварин зростала. Зокрема, концентрація МДА у тварин третьої групи склала $(4,83 \pm 0,13)$ мкмоль/л, що у 1,3 раза $(p<0,05)$ вище від норми, а у п'ятій групі тварин, яким використовували дексмедетомідин - $(4,31 \pm 0,07)$ мкмоль/л, що у 1,2 раза вище, порівняно з показниками у групі інтактних тварин $(p<0,05)$.

Гіпертиреоз супроводжується посиленням процесів вільнорадикального окиснення. Зафріксовано суттєве зростання активності МДА в групах із змодельованим гіпертиреозом при введенні тіопенталу натрію (IV група) у 2,1 раза $((7,84 \pm 0,10)$ мкмоль/л $(p<0,05))$ та 1,8 раза $((6,79 \pm 0,16)$ мкмоль/л $(p<0,05))$ у групі з дексмедетомідином (VI група) (табл. 2).

Висновки. Отримані нами результати показали, що в експерименті токсична дія засобів для наркозу проявляється в умовах гіпертиреозу більш виражено, ніж при еутиреозі.

Активація вільнорадикальних процесів призводить до збільшення рівня початкових та кінцевих продуктів ПОЛ та зриву фрізіологічних компенсаторних процесів і значних змін у процесах фролатного обміну, що є підставою рекомендувати застосування додаткової терапії в комплексній передопераційній підготовці на тлі гіпертиреозу.

Активація обмінних процесів щитоподібної залози впливає на універсальні системи захисту організму, що особливо яскраво проявляється в умовах операційного та періопераційного стресу порушенням фолатного обміну, що обумовлює підвищений ризик тромбоутворення, який $\epsilon$ особливо небезпечним у післяопераційному періоді і обумовлює пошук засобів медикаментозної корекції порушеного гомеостазу.

Pawilojc, M. Siekierska-Hellmann, A. Syrenicz, K. Sworczak // Endokrynol. Pol. - 2009. - Vol. 60 (6). - P. 443-448.

4. Сомова О. В. Взаємозв'язок стану щитовидної залози в організмі та процеси перекисного окислення ліпідів: дис. на здобуття наук. ступеня канд. наук за спеціальністю 03.00.13: Фізіологія людини і тварин / О. В. Сомова. - Харків : Українська мова, 1999.

5. Клінічний протокол післяопераційного ведення пацієнтів з диференційованим раком щитовидної залози / В. А. Олейник, В. В. Марков, С. В. Гулеватий [та ін.] // Ліки України. - 2010. - № 146 (10). - С. 73-75.

6. Окислювальна модифікація білків сироватки крові людини, метод ї̈̈ визначення / Є. Є. Дубініна, С. О. Бурмістров, 
Д. А. Ходов, І. Г. Поротов // Вопр. мед. хим. - 1995. - № 41 (1). - C. 24-26.

7. Науково-практичні рекомендації з утримання лабораторних тварин та роботи з ними / Ю. М. Кожем'якін, О. С. Хромов, М. А. Філоненко, Г. А. Сайоретдінова. - Київ : Авіценна, 2002. - 156 с.

8. Пат. на корисну модель UA 3386 (2004). Спосіб знеболення щурів під час операції на шлунку / Степанюк X. I., Шевчук О. К. ; заявник і патентовласник Вінницький нац. мед. університет ім. М. І. Пирогова. - No. 2004 020900; заявл. 09.02.2004; опубл. 15.11.2004. Бюл. №. 11.

9. Харкевич Д. А. Фармакология : учебник для студ. мед. вузов / Д. А. Харкевич. - М. : Медицина,1981. - 133 с.

10. Павлов А. А. Місце $\alpha 2$-агоністів у комбінованій анестезії / А. А. Павлов, Є. В. Подрез // Медицина невідкладних станів. - 2014. - № 8 (63). - С. 9-12.

11. Гаврилов В. Б. Спектрофотометрическое определе-

\section{REFERENCES}

1. Haugen, B.R., Alexander, E.K., Bible, K.C., Doherty, G.M., Mandel, S.J., Nikiforov, Yu.E., ..., \& Wartofsky, L. (2016). 2015 American thyroid association management guidelines for adult patients with thyroid nodules and differentiated thyroid cancer: the american thyroid association guidelines task force on thyroid nodules and differentiated thyroid cancer. Thyroid, 26 (1), 1-133.

2. Nechyporuk, V.M., Zaichko, N.V., \& Korda, M.M. (2017). Vplyv tyreoidnykh hormoniv na protsesy remetyluvannia ta transsulfuvannia sirkovmisnykh aminokyslot $v$ orhanakh shchuriv [Effect of thyroid hormones on the sulfur-containing amino acids remethylation and transsulfuration pathways in rats organs] Medychna ta klinichna khimiia - Medical and Clinical Chemistry, 19 (1), 12-16 [in Ukrainian].

3. Orzechowska-Pawilojc, A., Siekierska-Hellmann, M., Syrenicz, A., \& Sworczak, K. (2009). Homocysteine, folate, and cobalamin levels in hyperthyroid women before and after treatment. Endokrynol. Pol., 60 (6), 443-448.

4. Somova, O.V. (1999). Vzaiemozviazok stanu shchytovydnoi zalozy $v$ orhanizmi ta protsesy perekysnoho okyslennia lipidiv [The relationship between the state of the thyroid gland in the body and the processes of lipid peroxidation]. Candidate's thesis. Kharkiv: Ukrainska mova [in Ukrainian].

5. Oleynik, V.A., Markov, V.V., Gulevatyy, S.V., Matyashchuk, S.I., \& Sovenko, T.K. (2010). Klinichnyi protokol pisliaoperatsiinoho vedennia patsiientiv $z$ dyferentsiiovanym rakom shchytovydnoi zalozy [Clinical protocol of post-surgical management of patients with differentiated thyroid cancer]. Liky Ukrainy - Medicines of Ukraine, 146 (10), 73-75.

6. Dubinina, Ye.Ye., Burmistrov, S.O., Khodov, D.A., \& Porotov, I.G. (1995). Okysliuvalna modyfikatsiia bilkiv syrovatky krovi liudyny metod yii vyznachennia [Oxidative modification of human blood serum proteins method of its determination]. Vopr. med. khim. - Issues of Medical Chem., 41 (1), 24-26 [in Ukrainian].

7. Kozhemyakin, Yu.M., Khromov, O.S., Filonenko, M.A., \& Sayfetdinova, H.A. (2002). Naukovo-praktychni rekomendatsii z utrymannia laboratornykh tvaryn ta roboty z nym [Scientific and practical recommendations for keeping laboratory animals and working with them]. Kyiv: Avitsenna [in Ukrainian]. ние содержания гидроперекисей липидов в плазме крови / В. Б. Гаврилов, М. И. Мишкорудная // Лабораторное дело. - 1983. - № 3. - С. 33-36.

12. Ром-Бугуславская Е. С. Перекисное окисление липидов у пациентов с диффрузным токсическим зобом и гипотиреозом / Е. С. Ром-Бугуславская, Е. В. Сомова, Т. С. Гринченко // Лікарська справа. - 1998. - № 1. - С. 88-91.

13. Стальная И. Д. Метод определения малонового диальдегида с помощью тиобарбитуровой кислоты. Современные методы в биохимии / И. Д. Стальная, Т. Г. Гаришвили ; за ред. Орехович В. Н. - М.: Медицина, 1977. - С. 66-68.

14. Жабченко I. А. Сучасний погляд на роль фролатів у профрілактиці перинатальних проблем / І. А. Жабченко // Pепродуктивна ендокринологія. - 2019. - № 2 (46). - С. 57-61.

15. Wang Z. M. Folate and risk of coronary heart disease: a meta-analysis of prospective studies / Z. M. Wang, B. Zhou, Z. L. Nie // Nutr. Metab. Cardiovasc. Dis. - 2010. - Vol. 22 (10). - P. 890-899.

8. Stepaniuk, H.I., \& Shevchuk, O.K. (2004). Pat. Na korysnu model UA 3386 (2004). Sposib znebolennia shchuriv pid chas operatsii na shlunku [On the utility model UA 3386 (2004). Method of anesthesia of rats during gastric surgery]; zaiavnyk i patentovlasnyk Vinnytskyi nats. med. universytet im. M. I. Pyrohova, No. 2004 020900; zaiavl. 09.02.2004; opubl. 15.11.2004. Byul. No. 11. [in Ukrainian].

9. Kharkevich, D.A. (1981). Farmakologiya: uchebnik dlya stud. med. vuzov [Pharmacology: a textbook for students of medical universities]. Moscow: Meditsina [in Russian].

10. Pavlov, A.A., \& Podrez, Ye.V. (2014). Mistse a2-ahonistiv u kombinovanii anestezii [Place of $\alpha_{2}$-agonists in combined anesthesia]. Medytsyna nevidkladnykh staniv - Emergency Medicine, 8 (63), 9-12 [in Ukrainian].

11. Gavrilov, V.B., \& Mishkorudnaya, M.I. (1983). Spektrofotometricheskoye opredeleniye soderzhaniya gidroperekisey lipidov $v$ plazme krovi [Spectrophotometric determination of the content of lipid hydroperoxides in blood plasma]. Laboratornoye delo - Laboratory Matter, 3, 33-36 [in Russian].

12. Rom-Buguslavskaya, E.S., Somova, E.V., \& Grinchenko, T.S. (1998). Perekisnoye okisleniye lipidov u patsiyentov s diffuznym toksicheskim zobom i gipotireozom [Lipid peroxidation in patients with diffuse toxic goiter and hypothyroidism]. Vrachebnoe delo - Medicine, 1, 88-91 [in Russian].

13. Stalnaya, I.D., \& Garishvili, T.G. (1977). Metod opredeleniya malonovogo dialdegida s pomoshchyu tiobarbiturovoy kisloty. Sovremennyye metody $v$ biokhimii [Method for the determination of malonic dialdehyde using thiobarbituric acid. Modern methods in biochemistry]. Orekhovich, V.N. (Ed.). Moscow: Meditsina [in Russian].

14. Zhabchenko, I.A. (2019). Suchasnyi pohliad na rol folativ u profilaktytsi perynatalnykh problem [Modern view on the role of folate in the prevention of perinatal problems]. Reproduktyvna endokrynolohiia - Reproductive Endocrinology, 2 (46), 57-61 [in Ukrainian].

15. Wang, Z.M., Zhou, B., \& Nie, Z.L. (2010). Folate and risk of coronary heart disease: a meta-analysis of prospective studies. Nutr. Metab. Cardiovasc. Dis., 22 (10), 890-899.

Отримано 12.05 .20

Прийнято до друку 16.06.20

Електронна адреса для листування: sasha_yakimchuk@mail.ua 